\title{
Microbiological quality assessment of fresh tilapia marketed in the Federal District and of the ice used for its conservation
}

Avaliação da qualidade microbiológica de tilápia fresca comercializada no Distrito Federal e do gelo utilizado na sua conservação

\author{
A. C. A. O. Ferreira; E. S. Monteiro; D. O. Sousa; C. M. S. Silva; I. C. R. Silva; \\ D. C. Orsi*
}

Universidade de Brasília (UNB/FCE), Laboratório de Controle de Qualidade, Centro Metropolitano, Conjunto A, lote 01, Ceilândia, 72220-900, Brasília-DF, Brasil.

*danielacastilhoorsi@gmail.com

(Recebido em 16 de julho de 2021, aceito em 03 de novembro de 2021)

\begin{abstract}
Tilapia (Oreochromis niloticus) is the most cultivated and consumed freshwater fish in Brazil. The present study aimed to evaluate the microbiological quality of ice and fresh tilapia samples commercialized in the Federal District. Tilapia samples were tested for counts of mesophilic and psychrotrophic bacteria, determination of total and thermotolerant coliforms, Staphylococcus aureus counts and presence of Salmonella. Ice samples were analyzed for determination of total coliforms and thermotolerant coliforms and presence of Escherichia coli. Of the 20 samples of fresh tilapia analyzed, ten samples (50\%) presented Salmonella (genetically confirmed through the presence of the invA gene) and, therefore, were unfit for consumption. S. aureus was found in 11 samples (55\%), and one sample of fillet presented S. aureus counts (3.15 CFU/g) above the limit allowed by Brazilian legislation (3 log CFU/g). S. aureus colonies were confirmed by detection of CoA gene in molecular analysis. Of the 14 ice samples analyzed, 12 samples $(85.7 \%)$ were unfit for use in fish conservation due to the presence of total coliforms and 9 ice samples (64.3\%) were also contaminated with thermotolerant coliforms. E. coli was isolated from 6 ice samples (42.9\%) and confirmed in the molecular analysis through the amplification of the MalB gene. In conclusion, the high contamination of tilapia samples with Salmonella and of the ice used for its conservation with coliforms and E. coli indicates the need for better hygienic practices in the tilapia production chain, to increase its quality and microbiological safety.
\end{abstract}

Keywords: Oreochromis niloticus, freshwater fish, foodborne pathogens.

A tilápia (Oreochromis niloticus) é o peixe de água doce mais cultivado e consumido no Brasil. O presente estudo teve como objetivo avaliar a qualidade microbiológica de amostras de gelo e de tilápia fresca comercializadas no Distrito Federal. As amostras de tilápia fresca foram analisadas em relação a contagem de bactérias mesófilas e psicrotróficas, determinação de coliformes totais e termotolerantes, contagem de Staphylococcus aureus e presença de Salmonella. As amostras de gelo foram analisadas em relação a determinação de coliformes totais e termotolerantes e presença de Escherichia coli. Das 20 amostras de tilápia fresca analisadas, $10(50 \%)$ apresentaram Salmonella (confirmadas através da presença do gene invA) e, portanto, estavam impróprias para o consumo. Bactérias S. aureus foram encontradas em 11 amostras (55\%), e uma amostra de filé de tilápia apresentou contagem de $S$. aureus $(3,15 \mathrm{CFU} / \mathrm{g})$ acima do permitido pela legislação brasileira $(3 \log \mathrm{UFC} / \mathrm{g}$ ). As colônias de $S$. aureus foram confirmadas pela detecção do gene CoA. Das 14 amostras de gelo analisadas, 12 (85,7\%) estavam impróprias para uso na conservação do pescado devido à presença de coliformes totais e 9 amostras $(64,3 \%)$ também estavam contaminadas com coliformes termotolerantes. Bactérias E. coli foram identificadas em 6 amostras de gelo $(42,9 \%)$ e confirmadas pela amplificação do gene MalB. A elevada contaminação das amostras de tilápia com Salmonella e do gelo utilizado na sua conservação com coliformes e bactérias E. coli indica a necessidade de melhores práticas de higiene na cadeia produtiva da tilápia, para garantir a sua segurança e qualidade microbiológica.

Palavras-chave: Oreochromis niloticus, peixe de água doce, patógenos de origem alimentar.

\section{INTRODUCTION}

Tilapia (Oreochromis niloticus) is a popular farmed freshwater fish in the world [1]. A total of 323.700 tons of tilapia was produced in Brazil, corresponding to $61.1 \%$ of the total aquaculture 
fish production [2]. The advantages of farming tilapia are its rapid growth, relatively resistance to various diseases, and tolerance to changing environmental conditions. It is simple to culture tilapia intensively and economically. Tilapia presents an excellent meat quality and taste, with white-color and the absence of intramuscular bones [3-5].

Fish is an essential source of protein and provides many health benefits; however, it is a very perishable product and possesses a tendency for rapid microbial spoilage [5, 6]. It has been shown that fish can cause foodborne illnesses [3, 7]. In United States it was reported 857 outbreaks associated with the consumption of fish, resulting in 4815 illnesses, 359 hospitalizations and 4 deaths, during the period 1998-2015 [8]. Outbreaks associated with the consumption of fish and fishery products increased markedly in the European Union (EU) (by 80 outbreaks; $101.3 \%$ more than in 2018) even if this rise was entirely attributable to France which reported 129 outbreaks ( $81.1 \%$ of total outbreaks in the EU). The fish and fishery products were the food most frequently implicated in strong evidence outbreaks in the EU in 2019 [9]. In Brazil, 12503 cases of outbreaks were reported in the period 2000-2017 and fish consumption was associated with $0.83 \%$ of these outbreaks [10].

The fish bacterial flora depends on the water quality of where they live. Penetration and establishment of pathogenic bacteria such as Escherichia coli and Salmonella spp. in different fish tissues and organs, such as digestive tract, gills, and muscle have been reported in polluted aquatic environments [11-13].

The handling practices observed after the capture until the storage influence the fish shelf life. Inadequate fish handling and cross-contamination can contaminate the fish with foodborne pathogens, such as E. coli, Salmonella, and S. aureus [12,13]. Temperature is an important factor influencing the freshness of fish. Thus, to slow the growth of bacteria in fish, ice is used as a preservation method. Chilling slows down the deterioration of stored fish $[14,15]$.

Ice used in fish chilling must be of the same microbiological quality as drinking water [16]. Since almost all known bacterial enteropathogens of the Enterobacteriaceae, including E. coli, have been found in water, contamination of ice samples with these pathogens is possible. It is necessary to keep the microbiological ice quality to avoid cross-contamination of fish $[17,18]$.

When improper handling and storage occurs, the fish deteriorates rapidly, and its shelf life decreases. The high levels of microbiological contamination may pose a potential public health risk with the consumption of fish $[6,13]$. Hence, this study aimed to evaluate the microbiological quality of ice and fresh tilapia samples commercialized in the Federal District.

\section{MATERIALS AND METHODS}

\subsection{Microbiological analyses of fish}

The samples analyzed in this study were collected from different supermarkets in the Federal District, Brazil, from July 2018 to June 2019. Fish samples were represented by whole fresh tilapia (10 samples) and by 200-300 g of fresh tilapia fillets (10 samples), totalizing 20 samples. Note that the filleting process of tilapia is not done in supermarkets, but the fish processing industry. A total of fourteen ice samples were gathered and placed in sterile plastic bags in the form of flakes. The samples were analyzed in triplicate, and their results were expressed as mean.

For microbiological evaluation of tilapia fish, $25 \mathrm{~g}$ of each sample was diluted in $225 \mathrm{~mL}$ of $0.1 \%$ peptone water. The material was homogenized, thus obtaining the first dilution $\left(10^{-1}\right)$. From the first dilution the other decimal dilutions were obtained (up to $10^{-5}$ ). Microbiological analyzes included total counts of mesophilic and psychrotrophic bacteria, determination of total and thermotolerant coliforms, research of Salmonella spp. and counts of Staphylococcus aureus and were performed according to official methods from American Public Health Association -APHA [19].

For mesophilic and psychrotrophic bacteria counts, the dilutions of the samples were surface plated on Plate Count Agar (HiMedia, USA), following incubation at $37^{\circ} \mathrm{C}$ for $24 \mathrm{~h}$ for mesophilic bacteria and at $8^{\circ} \mathrm{C}$ for 7 days for psychrotrophic bacteria. 
Total and thermotolerant coliforms were determined by most probable number technique. For this, the dilutions of the samples were transferred to tubes containing Lauryl Sulfate Tryptose broth (LST) (HiMedia, USA) with Durhan tubes in its interior. After $24 \mathrm{~h}$ of incubation at $37^{\circ} \mathrm{C}$ in LST, aliquots from positive cultures (determined by turbidity and gas production) were transferred to tubes containing Brilliant Green Bile Broth 2\% (HiMedia, USA) for enumeration of total coliforms (incubated at $37^{\circ} \mathrm{C}$ for $24 \mathrm{~h}$ ), and to tubes containing E. coli broth (Acumedia, USA) for enumeration of thermotolerant coliforms (incubated at $45^{\circ} \mathrm{C}$ for $24 \mathrm{~h}$ ). Tubes with turbidity and gas production were considered positive for both tests.

For the research of Salmonella spp., the $10^{-1}$ dilution of the samples was incubated at $37^{\circ} \mathrm{C}$ for $24 \mathrm{~h}$. After incubation, aliquots were transferred to tubes containing $10 \mathrm{~mL}$ of Selenite Cystine broth (SC) (HiMedia, USA). A loopful of SC was streaked onto the xylose lysine deoxycholate agar (XLD) (Himedia, USA) and Salmonella Shigella agar (SS) (Himedia) and incubated at $37^{\circ} \mathrm{C}$ for $24 \mathrm{~h}$. Presumptive Salmonella colonies in XLD and SS agars were confirmed biochemically using triple sugar iron agar (TSI) (Himedia, USA) and lysine iron agar (LIA) (Himedia, USA) slants. These slants were incubated at $37^{\circ} \mathrm{C}$ for $24 \mathrm{~h}$. The presumptive Salmonella isolates that tested positive on TSI and LIA were confirmed by polymerase chain reaction (PCR).

For $S$. aureus counts, the dilutions of the samples were surface plated in Mannitol Salt Agar (HiMedia, USA) and incubated at $37^{\circ} \mathrm{C}$ for $48 \mathrm{~h}$. The colonies were counted and sub-cultured in Mannitol Salt Agar tubes. The characteristic colonies of $S$. aureus (yellow colonies with yellow zones, mannitol-fermenting) were stained by Gram's Method to confirm Gram-positive cocci. The colonies of $S$. aureus were further confirmed by PCR.

\subsection{Microbiological analyses of ice}

For microbiological evaluation of ice, the samples were analyzed for total coliforms and thermotolerant coliforms, according to Funasa (2006) [20]. The ice samples were placed and stored at $8^{\circ} \mathrm{C}$ until completely melted. For detection of total and thermotolerant coliforms, $10 \mathrm{~mL}$, $1 \mathrm{~mL}$ and $0.1 \mathrm{~mL}$ of melted ice were transferred to three series of five tubes containing Lauryl Sulfate Tryptose with Durhan tubes in its interior. Total coliforms were enumerated in Brilliant Green Bile Broth $2 \%$, incubated at $37^{\circ} \mathrm{C}$ for $24 \mathrm{~h}$ and thermotolerant coliforms were determined in $E$. coli broth (EC) incubated at $45^{\circ} \mathrm{C}$ for $24 \mathrm{~h}$. Tubes with turbidity and gas production were considered positive for both tests. From the EC broth, the phenotypical characteristic colonies of E. coli were isolated using MacConkey agar and then confirmed by PCR.

\subsection{Molecular analyses}

The bacteria S. aureus, Salmonella and E. coli were identified using the technique of polymerase chain reaction (PCR). Table 1 presents the primers CoA forward and reverse specific for the coagulase gene (Coa gene) of S. aureus, the primers InvA forward and reverse specific for the invasion A gene (invA gene) of Salmonella and the primers MalB forward and reverse specific for the formation of acetaldehyde and ammonia from ethanolamine (MalB gene) for the identification of E. coli.

For DNA extraction, the isolates were cultivated overnight in Mueller-Hinton broth and had their DNA extracted employing the NucleoSpin Food kit (Macherey-Nagel, Düren, Germany), as per the manufacturer's instructions. PCR was performed in a $25 \mu \mathrm{l}$ final volume reaction mixture containing: $2.5 \mu \mathrm{l}$ of PCR buffer; $0.7 \mu 1$ of $\mathrm{MgCl} 2 ; 1.5 \mu \mathrm{L}$ of dNTP $(2,5 \mathrm{mM}) ; 0.5 \mu 1$ of Taq DNA polymerase; $1.5 \mu \mathrm{L}$ of each primer forward and reverse; and $18.3 \mu \mathrm{l}$ of Milli-Q water. Thermal cycling reactions were conducted with Techne TC-512 thermal cycler (Bibby Scientific Inc., USA), and each PCR run included negative and reagent controls. The reagent control consisted of all PCR components except for the DNA template. The amplified DNA was separated by electrophoresis at $100 \mathrm{~V}$ for $50 \mathrm{~min}$ in $1.5 \%$ (w/v) agarose gel, stained with ethidium bromide and visualized under UV light. A 100 bp DNA ladder was used as a molecular weight marker. 
Table 1: Primers sequence of PCR used for identification of Staphylococcus aureus, Salmonella and Escherichia coli.

\begin{tabular}{clcc}
\hline Primer & \multicolumn{1}{c}{ Sequence 5'- $\mathbf{3}^{\prime}$} & $\begin{array}{c}\text { Amplified } \\
\text { product }\end{array}$ & Bacteria \\
\hline CoA forward & GATCTTCGCGTGATACGTCA & & \\
CoA reverse & GTTCGTGCAATGTTTGTCC & $303 \mathrm{pb}$ & Staphylococcus aureus \\
invA forward & GCTGATGCCGGTGAAATTAT & $103 \mathrm{bp}$ & Salmonella spp. \\
invA reverse & TGTCACCGTGGTCCAGTTTA & $113 \mathrm{bp}$ & Escherichia coli \\
$\begin{array}{c}\text { MalB forward } \\
\text { MalB reverse }\end{array}$ & $\begin{array}{l}\text { TCTATGGGCTGTGACTGCTG } \\
\text { GGCATCCCCATGATGTAGTT }\end{array}$ & & \\
\hline
\end{tabular}

\section{RESULTS AND DISCUSSION}

\subsection{Microbiological analyses of tilapia samples}

Table 2 shows the results of microbiological analyses in the samples of tilapia. The International Commission on Microbiological Specifications for Foods - ICMSF [21], recommends $7 \mathrm{log} \mathrm{CFU} / \mathrm{g}$ as the maximum acceptable limit for counting mesophilic and psychrotrophic bacteria in fresh fish.

Table 2: Microbiological analyses of tilapia samples.

\begin{tabular}{|c|c|c|c|c|c|c|}
\hline Samples & $\begin{array}{c}\text { MM } \\
(\log \mathrm{CFU} / \mathrm{g})\end{array}$ & $\begin{array}{c}\text { PM } \\
(\log \mathrm{CFU} / \mathrm{g})\end{array}$ & $\begin{array}{c}\text { TT } \\
(\log \text { MPN/g) }\end{array}$ & $\begin{array}{c}\text { TC } \\
(\log \text { MPN/g) }\end{array}$ & $\begin{array}{c}\text { S. aureus } \\
(\log \text { CFU/g) }\end{array}$ & $\begin{array}{c}\text { Salmonella } \\
\text { spp. }\end{array}$ \\
\hline \multicolumn{7}{|c|}{ Whole samples } \\
\hline 1 & $4.90 \pm 0.18$ & $5.36 \pm 0.05$ & $0.95 \pm 0.53$ & ND & $2.00 \pm 0.12$ & Negative \\
\hline 2 & $3.71 \pm 0.09$ & $1.16 \pm 2.00$ & $2.43 \pm 0.05$ & ND & $2.00 \pm 0.21$ & Positive \\
\hline 3 & $1.77 \pm 1.66$ & $4.23 \pm 0.12$ & ND & ND & ND & Negative \\
\hline 4 & $1.43 \pm 1.25$ & $3.46 \pm 0.27$ & $0.95 \pm 0.10$ & ND & $1.52 \pm 0.23$ & Positive \\
\hline 5 & $5.20 \pm 0.69$ & $6.25 \pm 0.62$ & $2.68 \pm 0.37$ & $2.00 \pm 0.62$ & ND & Negative \\
\hline 6 & $3.92 \pm 0.19$ & $4.85 \pm 0.30$ & $1.10 \pm 0.17$ & ND & ND & Negative \\
\hline 7 & $2.00 \pm 0.00$ & $5.84 \pm 0.20$ & $0.20 \pm 0.10$ & ND & ND & Positive \\
\hline 8 & $3.85 \pm 0.20$ & $5.08 \pm 0.83$ & $0.34 \pm 0.30$ & $0.50 \pm 0.05$ & ND & Negative \\
\hline 9 & $1.10 \pm 0.01$ & $2.89 \pm 0.19$ & $1.62 \pm 0.26$ & $0.20 \pm 0.61$ & $2.95 \pm 0.49$ & Negative \\
\hline 10 & $4.80 \pm 0.11$ & $3.63 \pm 0.11$ & $0.76 \pm 0.17$ & $\mathrm{ND}$ & $2.26 \pm 0.45$ & Positive \\
\hline \multicolumn{7}{|c|}{ Fillet samples } \\
\hline 11 & $6.31 \pm 0.21$ & $7.36 \pm 0.39$ & $3.04 \pm 0.10$ & $1.11 \pm 0.42$ & $2.84 \pm 0.10$ & Negative \\
\hline 12 & $5.90 \pm 0.42$ & $6.37 \pm 0.23$ & $2.81 \pm 0.30$ & $1.49 \pm 0.10$ & ND & Positive \\
\hline 13 & $4.80 \pm 0.10$ & $6.73 \pm 0.53$ & $1.90 \pm 0.23$ & $1.90 \pm 0.10$ & $2.00 \pm 0.42$ & Positive \\
\hline 14 & $5.71 \pm 0.09$ & $8.00 \pm 0.01$ & $1.90 \pm 0.10$ & $0.70 \pm 0.53$ & $2.65 \pm 0.01$ & Positive \\
\hline 15 & $5.85 \pm 0.42$ & $7.54 \pm 0.03$ & $2.90 \pm 0.22$ & ND & ND & Negative \\
\hline 16 & $3.09 \pm 0.10$ & $5.02 \pm 0.19$ & $1.00 \pm 0.55$ & ND & $3.15 \pm 0.21$ & Negative \\
\hline 17 & $4.28 \pm 0.12$ & $4.90 \pm 0.19$ & $2.53 \pm 0.45$ & $0.79 \pm 0.24$ & ND & Positive \\
\hline 18 & $5.83 \pm 0.15$ & $6.21 \pm 0.01$ & $1.91 \pm 0.65$ & ND & $2.20 \pm 0.17$ & Negative \\
\hline 19 & $5.59 \pm 0.38$ & $6.29 \pm 0.02$ & $1.76 \pm 0.26$ & $0.56 \pm 0.10$ & ND & Positive \\
\hline 20 & $4.18 \pm 0.17$ & $6.08 \pm 0.58$ & $0.63 \pm 0.20$ & ND & $2,15 \pm 0.21$ & Positive \\
\hline
\end{tabular}

$\mathrm{MM}=$ Mesophilic microorganisms; $\mathrm{PM}=$ Psychrotrophic microorganisms; $\mathrm{TT}=$ Total coliforms; $\mathrm{TC}=$ Thermotolerant coliforms. Samples 1-10: whole fresh tilapia; Samples 11-20: fresh tilapia fillets. Results reported as means \pm standard deviation of three measurements; ND $=$ not detected. 
In this study, of the 20 samples analyzed, 17 samples (85\%) showed acceptable mesophilic and psychrotrophic bacteria counts $(<7 \log \mathrm{CFU} / \mathrm{g})$ while 3 tilapia fillets samples $(15 \%)$ showed high counts of psychrotrophic bacteria (7.36-8.00 CFU/g). An increase in psychrotrophic bacteria counts to levels above $7 \log \mathrm{CFU} / \mathrm{g}$ is usually indicative of long storage at chilling temperatures or temperature abuse prior to chilling [22, 23].

Eltholth et al. (2018) [23] reported similar results for microbiological analyzes of farmed tilapia collected from Egyptian fresh fish markets, and more than $85 \%$ of samples tested were within the mesophilic bacteria counts $<7 \log$ CFU/g. In contrast, Budiati et al. (2015) [22] reported 20 of 32 tilapia samples $(62.5 \%)$ obtained from wet markets in Malaysia recorded counts of total bacteria higher than $7 \log$ CFU/g. According to Sundarambal et al. (2017) [24], freshwater fish species such as tilapia, rainbow trout, and silver perch reported mesophilic bacteria counts between 4 and $6 \log \mathrm{CFU} / \mathrm{g}$, furthermore, the gutting procedure can increase the initial load of microorganisms by exposing the fish flesh to environmental conditions.

According to Soares et al. (2014) [6], the enumeration of total coliforms is a good indicator of the quality and expected shelf life of the product. Most tilapia samples (95\%) showed acceptable enumeration of total coliforms $(<3 \mathrm{MPN} / \mathrm{g})$ and just one sample of fillet presented high enumeration of total coliforms (3.04 MPN/g). Gatti Junior et al. (2014) [13] reported higher total coliform enumeration in fillet compared to whole fish muscles. Sundarambal et al. (2017) [24] also reported that the total coliforms count in the gutted samples were higher than the whole samples.

The maximum value allowed for thermotolerant coliforms or E. coli in fresh fish is $2.7 \mathrm{log}$ $\mathrm{CFU} / \mathrm{g}$ according to Brazilian legislation [25]. In the present study, thermotolerant coliforms were detected in 9 tilapia samples (45\%), with values ranging from ND to $2 \log$ MPN/g. Gatti Junior et al. (2014) [13] reported similar results for thermotolerant coliforms (ND to 2 log MPN/g) in farmed tilapia collected from ten supermarkets located in the region of São Paulo, Brazil.

All the studied tilapia samples showed acceptable enumeration of thermotolerant coliforms $(<2.7 \mathrm{MPN} / \mathrm{g}$ ), though the fillet samples (7 positive samples from 10 analyzed, $70 \%$ ) were more contaminated with thermotolerant coliforms than whole samples ( 3 positive samples from 10 analyzed, 30\%). The filleting process can increase microbial contamination by exposing fish flesh to improper and unsanitary handling and cross-contamination $[13,24]$. The study of Rong et al. (2009) [26] reported changes in the microbial flora of filleted tilapia during iced storage to be higher than those in whole fish. This microbial contamination during fillet processing makes fish fillets difficult to sustain prolonged storage even under correct refrigeration. The storage life of tilapia can be expected to be 12 days for the whole fish and 6 days for the fillets.

The limit value for $S$. aureus in fresh fish is $3 \log$ CFU/g according to Brazilian legislation [25]. In the present study, S. aureus was found in 11 samples (55\%), and which one fillet sample presented $S$. aureus counts (3.15 CFU/g) above the limit allowed by Brazilian legislation. These results were confirmed by detection of the CoA gene. According to Gatti Junior et al. (2014) [13], cross-contamination of tilapia samples during the filleting process is an ongoing problem. In humans, $S$. aureus can be in the respiratory tract, nasal mucosa, and skin; and, therefore, inadequate food handling may contaminate food supply [27]. S. aureus is particularly harmful as it produces a thermostable toxin, which is one of the most prevalent causes of gastroenteritis [13].

The presence of Salmonella in fresh fish is unacceptable according to Brazilian legislation [25]. In this study, of the 20 samples of fresh tilapia analyzed, 10 samples $(50.0 \%)$ presented Salmonella (6 samples were fillets, and 4 samples were whole fish) and were confirmed as such by detection of the invA gene. Recently, some studies were carried out on the presence of Salmonella in cultivated freshwater fish [28-31]. Lerma-Fierro et al. (2020) [28] detected Salmonella spp. in 41.7\% (5/12) of fresh Nile tilapia fillets marketed in Tepic Nayarit city, Mexico. Elhadi (2014) [32] studied the proportion of imported frozen fish contaminated with Salmonella in Saudi Arabia and reported that of 25 tilapia samples imported from Thailand, 16 samples (64.0\%) were positive for Salmonella spp. Siala et al. (2017) [33] confirmed the presence of Salmonella using the InvA gene in 11 of 46 fish samples analyzed (23.9\%) in Tunisia.

Salmonella's primary habitat is the intestinal tract of warm-blooded animals, especially birds. and although Salmonella has also been found in the gut of different species of tropical fish, its never detected in fish caught in unpolluted waters as this bacterium is not part of the fish's natural 
microbiota [12,27]. Fisheries are particularly concerned by pathogenic bacteria contamination in polluted waters. Their presence in fish may cause a potential risk of causing foodborne illnesses $[11,12]$.

The use of poultry litter as fertilizer in culture tanks is another crucial factor contributing to Salmonella contamination in fish [12]. Elsaidy et al. (2015) [34] assessed the microbial water and Nile tilapia quality in ponds, using fertilized chicken manure and fermented chicken manure. Bacteriological analysis of water and fish samples of ponds revealed that the bacterial load that received fermented chicken manure was much lower than the bacterial load in ponds that received raw chicken manure. Also, E. coli and Salmonella were isolated with high incidence in ponds that received chicken manure than in ponds that received fermented chicken manure. According to Elsaidy et al. (2015) [34] the use of organic matter originating from animal feces, poses a risk to the water environment and represents great public health concern, owing to an increase in the concentrations of pathogenic microorganisms in system units with little exchange of water.

It was observed that from the total of 20 tilapia samples, 11 samples $(55 \%)$ were unfit for consumption: 4 samples of whole tilapia (20\%) and 7 samples of fillet (35\%) (Figure 1). This result of more fillet samples than whole samples unfit for consumption was also observed by Gatti Junior et al. (2014) [13]. According to the authors, possible sources of contamination of tilapia fillets may include the various utensils used (cutting board, knives), personnel (workers' hands) and the ice used to store the fish.

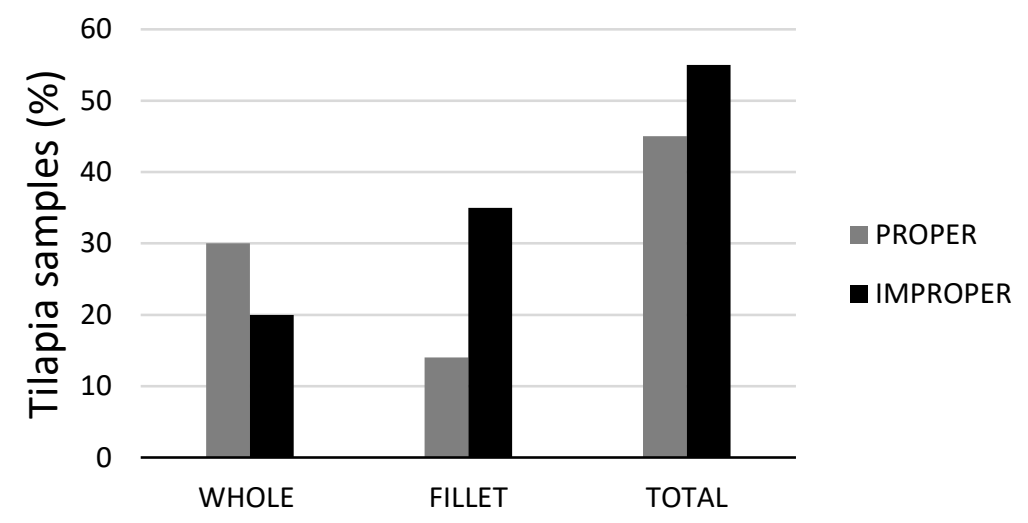

Figure 1: Percentage of tilapia samples proper and improper for consumption.

\subsection{Microbiological analyses of ice used in tilapia conservation}

To slow the growth of bacteria in fish ice is used as a conservation method. In this context, chilling is defined as the process of cooling fish or fish products to a temperature close to its freezing point by means of heat withdrawal $[14,35]$. Ice used in fish chilling must be of the same microbiological quality as drinking water. According to Brazilian legislation, total and thermotolerant coliforms must be absent in $100 \mathrm{~mL}$ of ice water, to guarantee the criteria for its potability [16]. Of the 14 ice samples analyzed in this study, 12 samples $(85.7 \%)$ were unfit for use due to the presence of total coliforms, and 9 (64.3\%) were also contaminated with thermotolerant coliforms. E. coli represents $90 \%$ of the composition of the thermotolerant coliforms group, therefore, of the 9 positive samples for thermotolerant coliforms, E. coli was isolated in 6 ice samples (42.9\%), and the strains were genetically confirmed by amplification of the MalB gene (Table 3). 
Table 3: Microbiological analyses of ice used in tilapia conservation.

\begin{tabular}{cccc}
\hline Ice Samples & $\begin{array}{c}\text { Total coliforms } \\
(\mathbf{l o g} \text { MPN/g) }\end{array}$ & $\begin{array}{c}\text { Thermotolerant coliforms } \\
(\mathbf{l o g} \text { MPN/g) }\end{array}$ & $\begin{array}{c}* \text { Escherichia } \\
\text { coli }\end{array}$ \\
\hline $\mathbf{1}$ & $3.20 \pm 0.05$ & $1.95 \pm 0.20$ & \\
$\mathbf{2}$ & $3.20 \pm 0.01$ & $2.45 \pm 0.30$ & MalB \\
$\mathbf{3}$ & $1.70 \pm 0.20$ & $1.34 \pm 0.05$ & MalB \\
$\mathbf{4}$ & $1.11 \pm 0.01$ & ND & \\
$\mathbf{5}$ & $0.60 \pm 0.45$ & $0.60 \pm 0.40$ & \\
$\mathbf{6}$ & $1.41 \pm 0.08$ & $0.78 \pm 0.30$ & \\
$\mathbf{7}$ & $\mathrm{ND}$ & $\mathrm{ND}$ & MalB \\
$\mathbf{8}$ & $\mathrm{ND}$ & $\mathrm{ND}$ & MalB \\
$\mathbf{9}$ & $1.24 \pm-0.10$ & $0.60 \pm 0.01$ & MalB \\
$\mathbf{1 0}$ & $1.23 \pm 0.07$ & $0.95 \pm 0.05$ & \\
$\mathbf{1 1}$ & $1.52 \pm 0.40$ & $1.32 \pm 0.20$ & MalB \\
$\mathbf{1 2}$ & $0.60 \pm 0.07$ & ND & \\
$\mathbf{1 3}$ & $3.20 \pm 0.01$ & $2.45 \pm 0.05$ & $\mathrm{ND}$ \\
$\mathbf{1 4}$ & $0.84 \pm 0.05$ & & \\
\hline
\end{tabular}

Results are reported as means \pm standard deviation of three measurements; ND: not detected; ${ }^{*} E$. col $l i$ were identified through the amplification of the MalB gene using PCR.

In Brazil, some studies reported a high level of coliforms in the ice used to preserve fish. Ferreira et al. (2014) [17] reported that of the 8 ice samples used for fish conservation collected in the city of Raposa, Maranhão, 6 samples (75\%) were contaminated by total and thermotolerant coliforms and 2 samples (25\%) by E. coli. Lopes et al. (2012) [36] evaluated the microbiological quality of ice samples from 3 factories located in Cedral, Maranhão, and all ice samples presented total coliforms. Dorta et al. (2011) [37] identified total coliforms and E. coli in all analyzed ice samples from factories in located the city of Teresina, Piaui.

Other studies reported contamination of ice used to cool drinks and foods. A study in Malaysia revealed the presence of thermotolerant coliforms in 36\% of samples of ice cubes from 30 foodservice outlets [38]. Mako et al. (2014) [39] reported that 37\% of samples of ice bagged from vending machines in Georgia contained coliforms bacteria.

The probable causes of ice contamination with total coliforms are the use of non-potable water for ice making, cross-contamination of ice and fish, and lack of hygiene during the production and handling of ice. The presence of thermotolerant coliforms and E. coli is a strong indication of recent fecal contamination. To avoid ice contamination personnel involved in the production and handling of ice should be trained in relative hygiene matters while ice-machines should be cleaned and disinfected regularly [38-40].

\section{CONCLUSIONS}

The results of this study showed high contamination of tilapia samples marketed in the Federal District with Salmonella. Of the 20 samples of fresh tilapia analyzed, 11 samples (55\%) were unfit for human consumption according to the Brazilian legislation, due to presence of Salmonella in 10 samples and 1 sample exceeds the limit counts for $S$. aureus. Most of the ice samples analyzed $(85.7 \%)$ were unfit for use in fish conservation due to the presence of total coliforms; moreover, $64.3 \%$ ice samples were also contaminated with thermotolerant coliforms. Thus, there is a need for greater hygienic-sanitary control during the tilapia production, processing, and marketing stages, as the presence of potentially pathogenic microorganisms may pose a potential public health risk among fish consumers. It is also an alert to the authorities to improve the inspection of good practices of storage and handling of fish and ice to guarantee the food safety of the consumer. 


\section{ACKNOWLEDGEMENTS}

This study was financed by FAPDF (Fundação de Apoio à Pesquisa do Distrito Federal (Edital 3/2018) and by Coordenação de Aperfeiçoamento de Pessoal de Nível Superior - Brasil (CAPES), Finance Code 001 for the scholarships.

\section{REFERENCES}

1. Food and Agriculture Organization of the United Nations (FAO). The state of world fisheries and aquaculture 2020. Sustainability in action. Rome: Food and Agriculture Organization of the United Nations; 2020. doi: 10.4060/ca9229en

2. Instituto Brasileiro de Geografia e Estatística (IBGE). Produção Pecuária Municipal [Internet]. Rio de Janeiro: IBGE; 2019 [cited 2021 Sep 10]. Available from: https://cidades.ibge.gov.br/brasil/pesquisa/1 $8 / 16459$

3. Cortés-Sánchez ADJ, Espinosa-Chaurand LD. Foods, fish and salmonellosis. African J Microbiol Res. 2018 Jun;12(23):525-35. doi: 10.5897/AJMR2018.8896

4. Igarashi MA. Aspectos técnológicos e perspectivas de desenvolvimento do cultivo de tilápia no Brasil. Arq Ciênc Vet Zool UNIPAR. 2019 Jul;21(3):123-30.

5. Morais CARS, Santana TP, Santos CA, Passetti RAC, Melo JFB, Macedo FAF, et al. Effect of slaughter weight on the quality of Nile tilapia fillets. Aquac. 2020 Apr;520:1-6. doi: 10.1016/j.aquaculture.2020.734941

6. Soares KMP, Gonçalves AA, Souza LB. Qualidade microbiológica de filés de tilápia do Nilo (Oreochromis niloticus) durante o armazenamento em gelo. Ciênc Rural. 2014 Dec;44(12):2273-78. doi: 10.1590/0103-8478cr20131065

7. Novoslavskij A, Terentjeva M, Eizenberga I, Valciņa O, Bartkevičs V, Bērziņš A. Major foodborne pathogens in fish and fish products: a review. Annals Microbiol. 2016 May;66:1-15. doi: 10.1007/s13213-015-1102-5

8. Barrett KA, Nakao JH, Taylor EV, Eggers C, Gould LH. Fish-associated foodborne disease outbreaks: United States, 1998-2015. Foodborne Pathog Dis. 2017 Sep;14(9):537-43. doi: 10.1089/fpd.2017.2286

9. European Food Safety Authority European Centre for Disease Prevention and Control. The European Union one health 2019 zoonoses report. EFSA J. 2021 Jan;19(2):6406. doi: 10.2903/j.efsa.2021.6406

10. Brasil. Ministério da Saúde. Surtos de Doenças Transmitidas por Alimentos no Brasil. Brasília: Secretaria de Vigilância em Saúde, Departamento de Vigilância das Doenças Transmissíveis; 2018.

11. Banigaa Z, Mdegelaa RH, Lisae B, Kusilukaa LJM, Dalsgaard A. Prevalence and characterisation of Salmonella Waycross and Salmonella enterica subsp. salamae in Nile perch (Lates niloticus) of Lake Victoria, Tanzania. Food Control, 2019 Jun;100:28-34. doi: 10.1016/j.foodcont.2019.01.006

12. Fernandes DVGS, Castro VS, Cunha Neto A, Figueiredo EES. Salmonella spp. in the fish production chain: a review. Ciênc Rural. 2018 Jul,48(8):e20180141. doi: 10.1590/0103-8478cr20180141

13. Gatti Junior P, Assunção AWA, Baldin JC, Amaral LA. Microbiological quality of whole and filleted shelf-tilapia. Aquac. 2014 Sep;433:196-200. doi: 10.1016/j.aquaculture.2014.06.015

14. Ahmed S, Akand NR, Islam MT, Mamun AA, Bari L. Effectiveness of scallop powder ice in reducing bacterial load on fresh whole fish and in the melted ice water. LWT - Food Sci Technol. 2015 Nov;64:270-4. doi: 10.1016/j.lwt.2015.06.002

15. Mohan CO, Ravishankar CN, Srinivasa GTK. Packaging interventions in low temperature preservation of fish - a review. MOJ Food Proc Technol. 2016 Feb;2(1):13-25. doi: 10.15406/mojfpt.2016.02.00026

16. Brasil. Ministério da Saúde, Agência Nacional de Vigilância Sanitária. Resolução - RDC n 274, de 22 de setembro de 2005. Aprova o Regulamento técnico para águas envasadas e gelo. Diário Oficial da União. 23 set 2005;184(Seção 1):376-377. Disponível em: https://bvsms.saude.gov.br/bvs/saudelegis/anvisa/2005/res0274-22_09_2005.html

17. Ferreira EM, Lopes IS, Pereira DM, Rodrigues LC, Costa FN. Qualidade microbiológica do peixe serra (Scomberomerus brasiliensis) e do gelo utilizado na sua conservação. Arq Inst Biol. 2014 Mar;81(1):4954. doi: 10.1590/S1808-16572014000100009

18. Moura CMC, Costa JA, Sousa AM, Santos Filho JH, Bacelar RGA, Santos JTO, et al. Avaliação da qualidade microbiológica de filés de tilápia-do-nilo (Oreochromis niloticus) e do gelo e a interação dos fatores após armazenagem. Med Vet. 2018 Jul;12(1):10-6. doi: 10.26605/medvet-v12n1-2137

19. American Public Health Association (APHA). Committee on Microbiological for Foods. Compendium of methods for the microbiological examination of foods. 4. ed. Washington: American Public Health Association; 2001. 
20. Fundação Nacional de Saúde (FUNASA). Manual Prático de Análise de Água. Brasília (DF): Assessoria de Comunicação e Educação em Saúde; 2006.

21. International Commission on Microbiological Specification for Foods (ICMSF). Microorganisms in foods. Sampling for micro-biological analysis: principles and specific applications. London: Blackwell Scientific Publications; 1986.

22. Budiati T, Rusul G, Wan-Abdullah WN, Ahmad R, Arip YM. Microbiological quality of catfish (Clarias gariepinus) and tilapia (Tilapia mossambica) obtained from wet markets and ponds in Malaysia. J Aquac Res Dev. 2015 Jan;6:1-5. doi: 10.4172/2155-9546.1000291

23. Eltholth M, Fornace K, Grace D, Rushton J, Häsler B. Assessing the chemical and microbiological quality of farmed tilapia in Egyptian fresh fish markets. Glob Food Secur. 2018 Jun;17:14-20. doi: 10.1016/j.foodpol.2015.01.002

24. Sundarambal JL, Kumar KNA, Sankar TV, Lalitha KV, Ninan G. Quality of monosex tilapia under ice storage: Gutting effects on the formation of biogenic amines, biochemical, and microbiological characteristics. Int J Food Prop. 2017 Nov;20(6):1368-77. doi: 10.1080/10942912.2016.1209777

25. Brasil. Agência Nacional de Vigilância Sanitária. Instrução Normativa $n^{\circ}$ 60, de 23 de dezembro de 2019. Estabelece as listas de padrões microbiológicos para alimentos. Diário Oficial da União. $26 \mathrm{dez}$ 2019;249(Seção 1):133-139. Available from: https://www.in.gov.br/en/web/dou/-/instrucao-normativan-60-de-23-de-dezembro-de-2019-235332356

26. Rong C, Chang-Hu X, Qi L, Bang-Zhong Y. Microbiological, chemical and sensory assessment of (I) whole ungutted, (II) whole gutted and (III) filleted tilapia (Oreochromis niloticus) during refrigerated storage. Int J Food Sci Technol. 2009 Oct;44:2243-8. doi: 10.1111/j.1365-2621.2009.02065.x

27. Pastro DC, Mariotto S, Santos EC, Ferreira DC, Chitarra GS. Use of molecular techniques for the analysis of the microbiological quality of fish marketed in the municipality of Cuiabá, Mato Grosso, Brazil. Food Sci Technol. 2019 Jun;39:146-51. doi: 10.1590/fst.40217

28. Lerma-Fierro AG, Flores-Lopez MK, Guzman-Robles ML, Cortes-Sanchez AJ. Microbiological evaluation of minimally processed and marketed fish in popular market of the city of Tepic Nayarit, Mexico sanitary quality of tilapia (Oreochromis niloticus). Tropic. 2020 Mar;38:1-19. doi: $10.25518 / 2295-8010.1556$

29. Santos PHC, Figueiredo HM, Silva LHM, Silva RSO, Cardoso GVF, Moraes CM, et al. Evaluation of a rapid detection method of Salmonella in comparison with the culture method and microbiological quality in fish from the Brazilian Amazon. Food Sci Technol. 2021 Oct;41(1):151-7. doi: $10.1590 /$ fst.38719

30. Cunha-Neto A, Panzenhagen P, Carvalho L, Rodrigues D, Conte-Junior C, Figueiredo E. Occurrence and antimicrobial resistance profile of Salmonella isolated from native fish slaughtered and commercialized in Brazil. J Food Saf Food Qual. 2019 Aug;70(4):94-8. doi: 10.2376/0003-925X-7094

31. Santos RR, Xavier, RGC, Oliveira TF, Leite RC, Figueiredo HCP, Leal CAG. Occurrence, genetic diversity, and control of Salmonella enterica in native Brazilian farmed fish. Aqua. $2019 \mathrm{Feb}$;501:30412. doi: 10.1016/j.aquaculture.2018.11.034

32. Elhadi N. Prevalence and antimicrobial resistance of Salmonella spp. in raw retail frozen imported freshwater fish to Eastern Province of Saudi Arabia. Asian Pac J Trop Biomed. 2014 Mar;4:234-8. doi: 10.1016/S2221-1691(14)60237-9

33. Siala M, Barbana A, Smaoui S, Hachicha S, Marouane C, Kammoun S, et al. Screening and detecting Salmonella in different food matrices in Southern Tunisia using a combined Enrichment/Real-Time PCR Method: correlation with conventional culture method. Front Microbiol. 2017 Dec;8:1-10. doi: 10.3389/fmicb.2017.02416

34. Elsaidy N, Abouelenien F, Kirrella GAK. Impact of using raw or fermented manure as fish feed on microbial quality of water and fish. Egypt J Aquat Res. 2015 Jan;41(1):93-100. doi: 10.1016/j.ejar.2015.01.002

35. Cyprian O, Oduor-Odote P, Lauzon H, Martinsdóttir E, Arason S. Microbiological quality and shelf life of fresh packaged tilapia fillets stored under different chill temperatures. J Microbiol Biotechnol Food Sci. 2013 Mar;2(4):2431-55.

36. Lopes IS, Costa FN, Ferreira EM, Pereira DM, Pereira LS, Cunha MCS. Pescada amarela (Cynoscion acoupa) desembarcada: características microbiológicas e qualidade do gelo utilizado na sua conservação. Rev Inst Adolfo Lutz. 2012 Dec;71(4): 677-84.

37. Dorta VF, Muratori MCS, Almeida CKS, Silva RM, Cardoso Filho FC. Condições higiênico-sanitárias do gelo utilizado para conservação do pescado nos mercados de Teresina, PI. Rev Hig Alim. 2011 Jun;25(196/197):124-8. 
38. Mahat NA, Meor Ahmad Z, Abdul Wahab R. Presence of faecal coliforms and selected heavy metals in ice cubes from food outlets in Taman Universiti, Johor Bahru, Malaysia. Trop Biomed. 2015 Sep;32(3):471-7.

39. Mako SL, Harrison MA, Sharma V, Kong F. Microbiological quality of packaged ice from various sources in Georgia. J Food Prot. 2014 Sep;77(9):1546-53. doi: 10.4315/0362-028X.JFP-13-398

40. Kassa H, Brian H, Karim B, Silverman GS. Microbial quality of ice machines and relationship to facility inspections in the Toledo, Ohio, area. J Environm Health. 2017 Nov;80(4):22-8. 